\title{
ADAPTABILITY OF MODERM SOYBEAN VARIETIES TO ENVIRONMENTAL STRESSES
}

Kucherenko Ye.Yu., Petrenkova V.P.

Plant Production Institute named after V.Ya. Yuriev of NAAS, Ukraine

We present the results of research into drought and cold tolerance of 34 modern soybean varieties developed in the leading breeding institutions of Ukraine. The objectives on evaluation of tolerance to abiotic factors by ability of seeds to germinate at low above-zero temperatures and insufficient moisture were achieved. Varieties with consistently (throughout the years) high cold tolerance and average drought tolerance in combination with increased (in comparison with the check varoeties) yields were identified and classified as valuable sources on grounds of their adaptability to stressful environmental conditions.

Key words: soybean, variety, cold tolerance, drought tolerance, abiotic factors, yield, adaptability

Introduction. Ukraine ranks the eighth in the world and the first in Europe in terms of soybean production ( $2016-2,28$ million tons, 2017 - 1,59 million tons) and has prospects for its further expansion due to agroclimatic resources, development of breeding and seed production, development and assimilation of cultivation technologies [1-3]. Under optimal conditions, domestic and foreign varieties produce comparable yields $(1,8-2,15 \mathrm{t} / \mathrm{ha})$, but under dry conditions, the yields of domestic varieties are twice and more as big as those given by foreign ones, due to their higher adaptability to the environment [4-6].

Review of Literature, Problem Statement. Studies by leading scientists of Ukraine, the USA, Canada, Sweden, Poland, and Russia demonstrated advantages of varieties suitable for early sowing due to the effective use of winter moisture reserves and formation of a significant portion of the yield before the onset of summer droughts, as well as of varieties adapted to water deficit [7]. Major indicators that depend on the environment are the seed germinability, the germination rate, dry aboveground biomass and yield of plants under extreme temperatures [8-9].

Climatic changes significantly affect the farming efficiency on the whole and encourage the search for new trends in the agrarian sector in Ukraine [10]. The dependence of agricultural crop yields on soil and climatic conditions remains extremely high [11]. Soil and atmospheric droughts [12] are often observed in the territory of our country. They cause stress responses in soybean plants, and insufficient adaptive plasticity of genotypes used in breeding as starting material has a negatively effect on seed yields [13-14]. Drought is the main negative factor among the complex of stress factors, which significantly reduce yields [15]. Soybean yields are especially strongly reduced because of water deficit (water stress) in the period from 30 to 40 days after the emergence of shoots. Drought occurring between 32 and 55 days after the emergence of shoots reduces the yield by $50 \%$ [16].

The difference between the initial and final temperatures has increased from $0,5^{\circ} \mathrm{C}$ to $1,2^{\circ} \mathrm{C}$ for over 100 years (1901-2005) [17]. Due to an decrease in rainfall since the 1970s, the number of very arid regions on Earth has more than doubled, and due to the global warming, which is going persist in the future, there is a very high risk that the number of intense droughts may increase even more [18].

Scientists from Canada, the USA, Sweden, Poland, Russia and other countries determined differences in the cold tolerance of soybean at the early stages of ontogenesis, depending on the genotype. Given the importance of the transfer of this valuable feature to the varieties that were being developed, prominent breeders VI Sichkar, VG Mikhaylov, VF Maryushkin, and MD Lunin paid considerable attention to this particular line of research, that is, the cold tolerance of soybean at the early stages of plant growth and development [19]. VF Maryushkin thought that a

(c) Ye.Yu. Kucherenko, V.P. Petrenkova. 2019.

ISSN 1026-9959. Селекція і насінництво. 2019. Випуск 115. 
$1-2^{\circ} \mathrm{C}$ increase in the cold tolerance during the germination and seed ripening stages provided 10-20 additional days for the photosynthetic activity of soybean plants, accumulation of storage substances, augmentation in the yield and improvement of the seed quality [20].

Numerous studies have found that reduction in the ambient temperature during the vegetation period increases the protoplasm viscosity. The less cold tolerant the genotype is, the more viscous its protoplasm becomes.

The main criteria for prospective soybean varieties, suitable for super-early sowing, which will give stable high yields, should be increased cold tolerance, which will ensure early shoots, and maintenance of the plant habitus and the total length of the growing period on shortened spring photoperiods [21-23].

Determination of the drought resistance and cold tolerance of starting material used in breeding programs to develop soybean varieties requires that breeding centers should have climatic chambers, phytotron equipment and other newest devices improving the effectiveness of evaluation methods and creation of new intensive high-yielding varieties, which would be characterized by complex resistance to unfavorable conditions of growth and development [24].

Current studies are mainly focused on developing universal varieties with increased protein content in seeds, tolerance to unfavorable environmental conditions, ability to fix significant amounts of nitrogen from the air. At the same time, the numbers of recessive genes, which are responsible for important traits, such as yield, led to a significant reduction in the adaptive responses of modern varieties. Therefore, at present, the priority trend in soybean breeding is to increase the adaptability of starting material to stressful conditions of cultivation [7].

Researchers from different countries revealed differences in the cold tolerance and drought resistance between soybean genotypes at the early stages of ontogenesis, which assisted to transfer these valuable features to newly-developed varieties [25-27, 19].

Therefore, in order to reduce losses caused by low above-zero temperatures and water deficit at the early stages of soybean ontogenesis, it is necessary to identify and implement coldtolerant and drought-resistant sources for the development of high-yielding varieties.

Purpose and Objectives. Our purpose was to evaluate drought resistance and cold tolerance of modern soybean varieties bred at the leading research institutions of Ukraine. Concurrently, a number of objectives were achieved: to identify varieties by ability of seeds to germinate at low above-zero temperatures and on water deficit as well as varieties combining high cold tolerance and drought resistance with consistently (throughout the years) increased (higher than those from the check varieties) yields.

Materials and Methods. We investigated 34 soybean varieties bred in Ukraine. Thirteen of which were developed at the Plant Production Institute named after VYa Yuriev of NAAS (PPI nd. a. VYa Yuriev) and enlisted in the State Register of Plant Varieties Suitable for Dissemination in Ukraine (Viktoryna, Krasunia, Baika, Estafeta, Malvina, Podiaka, Sprytna, Kobza, Pysanka, Raiduha, Perlyna, Melodiia, and Rizdviana). Four varieties were developed at the National Scientific Center "Institute of Agriculture of NAAS" (NSC IA) and enlisted in the State Register (Vilshanka, Siverka, Suziria, and Khvylia). Four varieties were developed at the Plant Breeding and Genetics Institute - National Center for Seed and Cultivar Investigations (PBGI NCSCI) and enlisted in the State Register (Melpomena, Farvater, Rusa, Siaivo). Four varieties (Sharm, Deni, Hali, and Rapsodiia) are from the Institute of Oil Crops of NAAS (IOC). Three registered varieties (Vezha, Khutorianochka and Kniazhna) and two promising varieties (Diadema and Triada) are from the Institute of Fodder and Agriculture of Podillia of NAAS (IFAP). Two registered varieties (Zolushka and Romashka) and two promising varieties (Zlata and Feieriia) are from the Institute of Agriculture of the Steppe Zone (IASZ).

The study was conducted for three years (2015-2017) in the laboratory and field conditions at the Plant Production Institute named after VYa Yuriev NAAS. Seeds harvested in different years were used in compliance with BA Dospekhov"s methods of field experimentation [28].

Drought resistance was assessed in the laboratory by VG Yatsenko"s method (1988), according to which seeds ( 25 seeds of each variety in 4 replicates) were sprouted in $8,8 \%$ sucrose in Petri dishes for five days at $23,0^{\circ} \mathrm{C}$. Concurrently, seeds of each accession were sprouted in distilled water (control). The percentage of seeds germinated in sucrose, i.e. under osmotic pressure, was calculated in relation to the number of control germinated seeds [24]. 
Cold tolerance was determined as described by T Chirkova, LA Lutova, et al., by the method known as "cold germination of seeds" [29]. The essence of this method is to sprout seeds in filter paper rolls ( 30 seeds in 4 replicates) at $10.0^{\circ} \mathrm{C}$ for seven days. The seed germinability was compared with the control, where seeds were sprouted in a thermostat under optimal for this crop conditions $\left(22,0-24,0^{\circ} \mathrm{C}\right)$. Seeds were considered as germinable if they formed corcules of a minimum length $(5 \mathrm{~mm})$. The cold tolerance of the varieties under investigation was assessed by comparing the germinability at $10,0^{\circ} \mathrm{C}$ with that at optimal temperatures and expressed as a percentage.

The yield of plants was determined upon cultivation of the varieties under investigation in the field on small plots of $1,2 \mathrm{~m}^{2}$. To evaluate the yield, plants were harvested manually from the plots. We measured the pod number per plant, the seed number per pod, the seed weight per plant, and the 1000-seed weight [30]. The yield of plants was compared with the check varieties of the corresponding ripeness groups. The very early varieties were compared with variety Annushka; early ones - with variety Diona; mid-early ones - with Kyivska 98; mid-ripening ones with variety Yatran; mid-late ones - with variety Vinnychanka; and late-ripening varieties - with check variety Melpomena.

The hydrothermal coefficient was determined by to AV Kuleshov, MO Bilyk and SV Dovhan's method [31]. This revealed differences in seed setting depending on weather conditions in the years differing in the hydrothermal coefficient (HTC) during the crop vegetation period. Two years (2014 and 2016) were characterized as optimal (HTC $=1,14$ in 2014 and $\mathrm{HTC}=1,32$ in 2016), and two years (2015 and 2017) - as dry (HTC $=0,6$ in 2015 and HTC $=0,4$ in 2017) [32].

Results and Discussion. Analysis of the laboratory data on cold tolerance investigated for three years showed that the varieties could be categorized into five groups according to the values determined by the "cold germination" as T Chirkova, AA Lutova, et al described: susceptible, with a percentage of germinated seeds of $0,0-20,0 \%$ related to the control, mildly tolerant $(21,0-40,0 \%)$, mid-tolerant $(41,0-60,0 \%)$, tolerant $(61,0-80,0 \%)$, and highly tolerant $(81,0-100,0 \%)$ (Table 1$)$.

Table 1

Distribution of Soybean Varieties between Cold Tolerance Groups

\begin{tabular}{lcl}
\hline \multicolumn{1}{c}{ Group } & Tolerance range, \% & \multicolumn{1}{c}{ Accession name } \\
\hline Intolerant & $0-20$ & \multicolumn{1}{c}{-} \\
Mildly tolerant & $21-40$ & Sharm, Vilshanka \\
Moderately tolerant & $41-60$ & $\begin{array}{l}\text { Raiduha, Perlyna, Pysanka } \\
\text { Baika, Diadema, Melodiia, Siverka, } \\
\text { Suziria, Rusa, Hali, Vezha, Sprytna, }\end{array}$ \\
Tolerant & $61-80$ & $\begin{array}{l}\text { Khvylia, Rizdviana, Farvater } \\
\text { Siaivo, Triada, Estafeta, Feieriia, } \\
\text { Podiaka, }\end{array}$ \\
Highly tolerant & $81-100$ & \\
\hline
\end{tabular}

There were differences the ability of seeds to germinate at the low above-zero temperature between the varieties, indicating their levels of cold tolerance at the initial stages of development. No cold susceptible varieties bred in Ukraine were detected. The mildly tolerant group only comprised two soybean varieties, Sharm and Vilishanka, their percentages of germinated seeds were $32,4 \%$ and $25,2 \%$, respectively, related to the corresponding controls. Three varieties (Raiduha, Perlyna and Pysanka) were mid-tolerant to cold, with the percentages of germinated of 58,3\%, $56,7 \%$ and $53,6 \%$, respectively, related to the corresponding controls. Twelve varieties or 35,3\% were referred to tolerant ones (Baika, Diadema, Melodiia, Siverka, Suziria, Rusa, Hali, Vezha, Sprytna, Khvylia, Rizdviana, and Farvater). The highly-tolerant group comprised 17 soybean varieties, which is $50,0 \%$ of the sample. These results attest to the high level of the domestic soybean breeding for cold resistance, as the percentages of germinated seeds of these varieties at $10{ }^{\circ} \mathrm{C}$ during seven days were within $80-100 \%$ as compared with the corresponding controls.

As to the soybean breeding for drought resistance, basing on the results obtained, we concluded that it was expedient to strengthen this line (Table 2). 
Distribution of Soybean Varieties between Drought Resistance Groups

\begin{tabular}{|c|c|c|}
\hline Tolerance group & Tolerance limits, $\%$ & Accession \\
\hline Susceptible & $0,0-20,0$ & Khutorianochka, Vilshanka \\
\hline Mildly-resistant & $21,0-40,0$ & $\begin{array}{l}\text { Rapsodiia, Diademaa, Triada, } \\
\text { Krasunia, Melodiia, Raiduha, Feieriia, } \\
\text { Pysanka, Suziria, Sprytna, Hali, Baika, } \\
\text { Kniazhna, Rizdviana, Sharm, Kobza, } \\
\text { Melpomena, Deni, Vezha, Rusa, } \\
\text { Khvylia, Viktoryna }\end{array}$ \\
\hline Mid-resistant & $41,0-60,0$ & $\begin{array}{c}\text { Siverka, Malvina, Farvater, Zlata, } \\
\text { Siaivo, Romashka, Zolushka, Perlyna, } \\
\text { Estafeta, Podiaka }\end{array}$ \\
\hline Resistant & $61,0-80,0$ & - \\
\hline Highly-resistant & $81,0-100,0$ & - \\
\hline
\end{tabular}

According to the ability of soybean seeds to sprout in osmotic solution, the varieties were categorized in the following groups with the corresponding percentages of germinated seeds: susceptible $(0,0-20,0 \%)$, mildly-resistant $(21,0-40,0 \%)$, mid-resistant $(41,0-60,0 \%)$, resistant $(61,0-80,0 \%)$, and highly-resistant $(81,0-100,0 \%)$. It was found that the most varieties (22 varieties or $64,7 \%$ of the sample) were mildly-resistant, since their percentages of germinated seeds were within $21,0-40,0 \%$ related to the corresponding controls. The mid-resistant group comprised 10 varieties or $29,4 \%$ of the total number of the investigated ones. There were two varieties with low seed germinability ( $\leq$ $20,0 \%$ ). No resistant or highly-resistant varieties with percentages of seeds sprouted in osmotic solution of $61,0-80,0 \%$ or $81,0-100,0 \%$, respectively, were found.

Summarizing the results of our analyses of modern soybean varieties for cold tolerance and drought resistance, we distinguished six varieties combining high cold tolerance $(82,7-$ $99,3 \%)$ and medium drought resistance (41,0-45,3\%). They are Siaivo (99,3\% cold tolerance, $44,0 \%$ drought resistance), Podiaka $(96,4 \%$ and $41,0 \%$, respectively), Malvina $(92,8 \%$ and $45,3 \%$, respectively), Romashka $(84,1 \%$ and $42,6 \%$, respectively), Zolushka $(83,8 \%$ and $42,3 \%$, respectively), and Zlata ( $82,7 \%$ and $44,4 \%$, respectively) (Table 3 ). Among the highly cold-tolerant varieties, there was one variety (Rapsodiia), which combined cold tolerance with high plant yield of $117,0 \%$ related to the corresponding check variety (Yatran, mid-ripening group). Diadema and Hali were cold tolerant (78,8 \% and 75,9\%, respectively), and their yields amounted to $115,0 \%$ and $104,0 \%$, respectively, related to the corresponding check variety. Some highly cold-tolerant varieties consistently (during the three study years) gave yields that were equal to or slightly higher than the yields from the corresponding check varieties. Thus, the yields from varieties Deni, Khutorianochka, Kniazhna, and Viktoryna were 100,0 \%, 101,0\%, $103,0 \%$, and 96,0\%, respectively (Table 4).

Table 3

\section{Soybean Varieties - Sources of High Cold Tolerance and Medium Drought Resistance at the Early Stages of Ontogenesis, 2015-2017.}

\begin{tabular}{cccccccc}
\hline \multirow{2}{*}{ Accession } & \multirow{2}{*}{$\begin{array}{c}\text { Institution - } \\
\text { originator }\end{array}$} & \multicolumn{3}{c}{ Drought resistance } & \multicolumn{3}{c}{ Cold tolerance } \\
\cline { 3 - 7 } & & 2015 & 2016 & 2017 & 2015 & 2016 & 2017 \\
\hline Podiaka & PPI & 19,4 & 54,4 & 49,3 & 93,3 & 95,8 & 98,9 \\
Malvina & PPI & 40,3 & 41,2 & 54,5 & 90,7 & 91,7 & 94,4 \\
Siaivo & PBGI - NCSCI & 6,7 & 49,3 & 76,0 & 99,7 & 99,0 & 99,2 \\
Romashka & IASZ & 28,8 & 48,1 & 50,7 & 82,3 & 84,5 & 85,7 \\
Zolushka & IASZ & 37,7 & 65,0 & 24,2 & 82,9 & 86,9 & 79,5 \\
Zlata & IASZ & 26,3 & 54,0 & 52,8 & 97,9 & 77,8 & 72,4 \\
\hline
\end{tabular}


Таблиця 4

Soybean Varieties - Sources of cold resistance in combination with plant productivity, 2015-2017.

\begin{tabular}{|c|c|c|c|c|c|c|}
\hline \multirow[b]{2}{*}{ Accession } & \multirow{2}{*}{$\begin{array}{l}\text { Institution - } \\
\text { originator }\end{array}$} & \multicolumn{4}{|c|}{ Cold tolerance, $\%$} & \multirow{2}{*}{$\begin{array}{c}\text { Yield related to } \\
\text { the check } \\
\text { variety, } \%\end{array}$} \\
\hline & & 2015 & 2016 & 2017 & Average & \\
\hline Podiaka & PPI & 93,3 & 95,8 & 98,9 & 96,0 & 58,0 \\
\hline Malvina & PPI & 90,7 & 91,7 & 94,4 & 92,3 & 70,0 \\
\hline Viktoryna & PPI & 83,4 & 84,2 & 83,8 & 83,8 & 96,0 \\
\hline Rapsodiia & IOC & 92,3 & 88,0 & 96,7 & 92,3 & 117,0 \\
\hline Hali & $\mathrm{IOC}$ & 83,3 & 94,4 & 50,0 & 75,9 & 104,0 \\
\hline Deni & IOC & 84,7 & 95,4 & 85,7 & 88,6 & 100,0 \\
\hline Siaivo & PBGI - NCSCI & 99,7 & 99,0 & 99,2 & 99,3 & 53,0 \\
\hline Romashka & IASZ & 82,3 & 84,5 & 85,7 & 84,1 & 68,0 \\
\hline Zolushka & IASZ & 82,9 & 86,9 & 79,5 & 83,1 & 91,0 \\
\hline Zlata & IASZ & 97,9 & 77,8 & 72,4 & 82,7 & 91,0 \\
\hline Diadema & IFAP & 49,3 & 88,9 & 96,5 & 78,2 & 115,0 \\
\hline Kniazhna & IFAP & 79,4 & 87,3 & 86,5 & 84,4 & 103,0 \\
\hline Khutorianochka & IFAP & 88,8 & 98,8 & 68,5 & 85,3 & 101,0 \\
\hline
\end{tabular}

Conclusions. In the three-year study of 34 soybean varieties bred at the leading breeding institutions of Ukraine their cold tolerance and drought resistance were evaluated by sprouting seeds at low above-zero temperatures ("cold germination") and in osmotic solution imitating a moisture lack. The varieties were categorized into groups, and valuable sources with high and medium cold tolerant and drought resistance were selected. We identified 13 cold-tolerant and highly cold-tolerant varieties - sources of cold tolerance, among which three varieties (Podiaka, Malvina and Viktoryna) were developed at the PPI nd. a. VYa Yuriev NAAS; three varieties (Rapsodiia, Hali and Deni) - at the IOC NAAS; one variety (Siaivo) - at the PBGI - NCSCI; three varieties (Romashka, Zolushka and Zlata) - at the IASZ. There were six varieties - sources of medium drought resistance (Podiaka, Malvina, Siaivo, Romashka, Zolushka, and Zlata).

Among the 13 soybean varieties distinguished by cold tolerance, six varieties (Viktoryna, Hali, Deni, Diadema, Kniazhna, and Khutorianochka) produced the yields that were equal to $(96,0-115,0 \%)$ or higher than (Rapsodiia, $117,0 \%)$ that of the check variety.

The results obtained indicate that there is valuable breeding material in research institutes of NAAS, which will contribute to the development of new soybean varieties with increased ability to sprout at low temperatures and on water deficit. Varieties with consistently mild drought resistance, but with cold tolerance combined with high and moderate performance, are economically feasible to grow on optimal moistening; they are also suitable for super-early sowing.

\section{References}

1. Riabukha S.S., Chernyshenko P.V., Mahomedov R.D., Posylaieva O.O., Sokol T.V. Soybean breeding, seed production and cultivation technology in the eastern forest-steppe of Ukraine. Fundamentals of field crop production management: monograph. V.V. Kyrychenko, V.P. Petrenkova, L.N. Kobyzieva [et al]; edited by V.V. Kyrychenko. Kh.: Private Enterpriser Brovin O.V., 2016. 712 p.

2. Zhuchenko A.A. Strategy of adaptive intensification of agriculture. Pushchino ONTI PNTs RAN. 1994. 148 p.

3. Zhuchenko A.A. Ecological genetics of domestic plants: theory and practice. Selskokhozyaystvennaya Biologiya. 1995. No 3. P. 4-31.

4. Petrichenko V.F., Ivanyuk S.V., Kolesnik S.I. Adaptive breeding of soybean and scientificallygrounded elements of varietal technology of soybean cultivation in the forest-steppe of Ukraine. Current Problems of Soybean Breeding and Cultivation Technology: Abstract book of the $2^{\text {nd }}$ International Conference on Soybean. Krasnodar, September 9-10, 2008. P. 24-27. 
5. Ustarkhanova E.G., Cherezov R.N. Characterization of soybean varieties bred in Armavir. $8^{\text {th }}$ International Conference of Young Scientists and Professionals. VNIIMK. 2015. P. 179-181.

6. Mikhailov V.H., Shcherbina O.Z., Romaniuk L.S., Starychenko V.M. Characteristics of fastand mid-ripening soybean varieties for the forest-steppe and woodlands of Ukraine. Internet link. Access at http://www.soya.biz.ua/component/content/article/90-selektsiya/115kharakteristika-skorostiglikh-i-serednostiglikh-sortiv-soji.

7. Sichkar V.I. Results, problems and prospects of soybean and pea breeding for the steppe zone of Ukraine. Collection of scientific works of PBGI - NCSCI: dedicated to the $100^{\text {th }}$ anniversary of the Istitute. Odesa. 2012. Issue 20 (60). P. 78-82.

8. Balashov T.N., Sherepitko V.V. On soybean breeding for cold tolerance. Genetic basics of agricultural crop breeding in Moldova. - Chisinau: Shtiintsa, 1986. P.114-121.

9. Kurlovich B.S. Repyev S.I. Shchelko L.G., Budanova V.I. Petrova M.V. Gene pool and breeding of grain legumes (lupine, vetch, soybean, bean). Theoretical principles of plant breeding. St. Petersburg: VNIIR. 1995. 438 p.

10. Petrychenko V.F. Scientific basics of soybean production and use in animal husbandry. Kormy i Kormovyrobnytstvo: Interdepartmental thematic collection of scientific works. Kyiv: Urozhai, 2012. Issue 71. P. 3-11.

11. Zhuchenko. A.A. Adaptive potential of domestic plants (ecological and genetic bases). Chisinau: Shtiintsa, 1988. 400 p.

12. Latysh L.H., Khokhlov V.M. Changes in the water content in soil in Ukraine in 2011-2015. Fizychna Heohrafiia ta Heomorfolohiiia. Kyiv: VHL "Obrii", 2009. Issue. 57. P. 43-49.

13. Lialko I.V., Yelistratova L.O., Apostolov O.A. Research into problems of aridity in the territory of Ukraine using terrestrial and satellite information. Ukrainskyi Zhurnal Lystantsiinoho Zonduvannia Zemli. 2014. No. 2. P. 18 - 28.

14. Babych A.O., Babych-Poberezhna A.A. Soybean breeding and production in Ukraine. Vinnytsia, 2008. P. 14-16.

15. Altergot V.F. Effect of elevated temperature on plants in experiment and nature. Moscow: Nauka, 1981. P. 56.

16. Mingea M. Etude de la sensibilite du soja. A la sechersse. Informtechn. CETION 1975 N 47. P. 1-15.

17. Barabash M.B., Tatarchuk O.H., Hrebeniuk N.P., Korzh T.V. Practical direction of research into climatic changes in Ukraine. Fizychna Heohrafiia ta Heomorfolohiiia. Kyiv: VHL "Obrii", 2009. Issue 57. P. 28-37.

18. Solomon S. Climate Change 2007: The Physical Science Basis. Contribution of the Working Group I to the fourth assessment report of the intergovernmental panel on climate change. Cambridge University Press, 2007, p. 231-237.

19. Sherepitko V.V. Genetic bases of adaptive soybean breeding: author's synopsis of the thesis for the Academic Degree of Doctor of Agricultural Sciences: specialty 03.00.15 "Genetics". Kyiv, 2002. 29 p.

20. Maryushkin V.F., Mikhaylov V.G., Livshits L.A., Polivoda L.V. Variability and inheritance of the germination rate of soybean seeds at a reduced temperature. Soybean Biology, Breeding and Genetics. Novosibirsk, 1986. P. 33-41.

21. Zelentsov S.V., Moshnenko Ye.V. Propsects of use of super-early soybean crops in the Krasnodar region. Maslichnyye Kultury: Scientific and technical bulletin of the All-Russian Research Institute of Oil Crops. 2010. Issue 1 (142-143). P. 87-94.

22. Zelentsov S.V., Moshnenko Ye.V. Breeding-genetic adaptation of soybean to growing seasonal aridization of the European South of Russia. Posibnyk Ukrainskoho Khliboroba. Vinnytsia. Vol. 2. P. 257-258.

23. Moshnenko Ye.V. [et al.] Identification of cold-tolerant soybean lines with stable yields upon super-early and optimal sowing time. Modern Trends in the Development of Science and Technology: Abstract book of the $20^{\text {th }}$ International Scientific and Practical Conference (November 30, 2016). Belgorod, 2016. P. 20-24. 
24. Drozdov S.N., Udovenko G.V. Diagnostics of plant resistance to stress factors. VIR. Leningrad, $1988.63 \mathrm{p}$.

25. Littlejohns D., Tanner J. Preliminary studies on the cold tolerance of soybeans seedlings. Canad J. Plant Sci. 1976 Vol. 56. No 2. P. 371.

26. Gupta D., Kovacs A. Cold tolerance of parents, single, 3-way and double crosses of opaque bread inbreds and their normal analogues. Euphytica 1975. Vol. 24. No 1. P. 245.

27. Mock J. J., McNeill M. J. Cold Tolerance of Maize Inbread Lines Adapted to Different Latitudes in North America. - Crop Sci. 1979. Vol. 19. No 2. P. 239.

28. Dospekhov B.A. Methods of field experimentation (with basics of statistical processing of study data). Moscow: Agropromizdat, 1985. $351 \mathrm{p}$.

29. Polevoy V.V. Chirkova T.V. Lutova L. A.A. Tutorial on plant growth and resistance: tutorial. Edited by V.V. Polevoy, T.V. Chirkova. St. Petersburg: Publishing House of St. Petersburg University. 2001.212 p.

30. CMEA ${ }^{\text {es }}$ international classifier of the genus GLYCINE WILLD. Leningrad, 1990. $46 \mathrm{p}$.

31. Kulieshov A.V., Bilyk M.O., Dovgan S.V. Phytosanitary monitoring and prediction. $2^{\text {nd }}$ revised and enlarged edition: tutorial. Kharkiv: Espada. 2011. 608 p.

32. Determination of donor properties of sources of resistance to biotic factors, their introduction into breeding programs: Report on the study "Diversity of the Gene Pool of Field Crops for Resistance to Pathogens and Pests" within project 24.01.01.02.F. Kharkiv, 2017. 68 p.

\section{АДАПТИВНИЙ ПОТЕНЦАЛ СУЧАСНИХ СОРТІВ СӦ̈ ДО СТРЕСОВИХ УМОВ СЕРЕДОВИЩА}

Кучеренко Є.Ю., Петренкова В.П.

Інститут рослинництва ім. В.Я. ЮреєваНААН, Україна

Мета. Визначити рівень посухо- та холодостійкості сучасних сортів сої селекції провідних науково-дослідних установ України.

Матеріали і методи. Лабораторнs - пророщування насіння в розчині осмотика для визначення посухостійкості та холодне пророщування насіння для визначення холодостійкості. Польові - визначення рівня врожайності.

Обговорення результатів. Сорти сої провідних науково-дослідних установ Національної академії аграрних наук України (IP ім. В.Я. Юреєва - 13 сортів, ННЦ І3 - 4, СГІ-НЦНС - 4, ІОК - 4, ІКСГП - 5, КГСГДС - 4) за аналізом лабораторних досліджень 2015-2017 pp. розподілено на групи стійкості до посухи та холоду. Встановлено незначні відмінності між сортами за посухостійкістю. Серед досліджених 34 сортів два віднесено до групи нестійких, так як часка насінин, що проросли у розчині осмотика, по відношенню до контролю не перевищувала 20,0 \%. Групу слабкостійких склали 22 сорти, у яких кількість пророслого насіння була в межах 21,0-40,0 \%. Середньою стійкістю характеризувались 10 сортів (41,0-60,0 \% пророслого насіння до контролю). Стійких до посухи сортів сої (61,0-80,0 \% пророслого насіння) та високостійких (81,0-100,0 \%) не виявлено. За стійкістю до холоду сорти сої вітчизняної селекції сильно варіювали по групах стійкості в межах кількості пророслого насіння при зниженій позитивній температурі $+10,0{ }^{\circ} \mathrm{C}$. Нестійких сортів 3 пророслим насінням 0,0-20,0 \% до контролю не виявлено. Два сорти віднесено до групи слабкостійких з рівнем пророслого насіння в межах 21,0 40,0 \%, середньостійких (41,0-60,0 \% пророслого насіння) було три сорти, стійких $(61,0-80,0 \%)-12$ сортів, високостійких (81,0-100,0 \%) - 17 сортів. За врожайністю відповідно рівню перевищення стандарту в межах 53,0-117,0 \% виявлено сім сортів 3 урожайністю на рівні стандарту.

Висновки. За результатами трирічних досліджень 34 сортів сої вітчизняної селекції за рівнем посухо- та холодостійкості за часткою пророслого насіння в осмотикові (посухостійкість) та холодного пророщування (холодостійкість) виділено сорти, які відповіда- 
ють категорії джерела стійкості до абіотичних чинників. Серед них 13 сортів з високою холодостійкістю (75,9-99,3 \% пророслого насіння при зниженій позитивній температурі $\left.+10,0^{\circ} \mathrm{C}\right)$ та 10 сортів із середньою стійкістю до посухи (41,0-60,0 \%).

Ключові слова: сорт, соя, холодостійкість, посухостійкість, абіотичний чинник, урожайність, адаптивність

\section{АДАПТИВНЫЙ ПОТЕНЦИАЛ СОВРЕМЕННЫХ СОРТОВ СОИ К СТРЕСОВЫМ УСЛОВИЯМ СРЕДЫ}

Кучеренко Е.Ю., Петренкова В.П.

Институт растиниеводства им. В.Я. Юрьева НААН, Украина

Цель. Определить уровень засухо и холодоустойчивости современных сортов сои селекции ведущих научно-исследовательских учреждений Украины.

Материалы и методы. Лабораторные - проращивание семян в растворе осмотика для определения засухоустойчивости и холодное проращивание семян для определения холодоустойчивости. Полевые - определение уровня урожайности.

Обсуждение результатов. Сорта сои ведущих научно-исследовательских учреждений Национальной академии аграрных наук Украины (ИР им. В.Я. Юрьева - 13 сортов, ННЦ ИЗ - 4, СГИ - НЦНС - 4, ИМК - 4, ИКСХП - 5, КГСХОС - 4) по анализу лабораторных исследований 2015-2017 гг. разделены на группы устойчивости к засухе и холоду. Обнаружено незначительное различие между сортами по засухоустойчивости. Среди исследованных 34 сортов два отнесены к группе неустойчивых, так как доля проросших семян в растворе осмотика по отношению к контролю не превышала $20,0 \%$. Группу слабоустойчивых составили 22 сорта, в которых количество проросших семян было в пределах 21,0-40,0\%. Средней устойчивостью характеризовались 10 сортов (41,0-60,0\% проросших семян к контролю). Устойчивых к засухе сортов сои $(61,0-$ $80,0 \%$ проросших семян) и высокоустойчивых (81,0-100,0\%) не обнаружено. По устойчивости к холоду сорта сои отечественной селекции имели больший уровень вариабельности по группам устойчивости в пределах количества проросших семян при пониженной положительной температуре $+10,0{ }^{\circ} \mathrm{C}$. Неустойчивых сортов с проросшими семенами 0,0-20,0 \% к контролю не обнаружено. Два сорта отнесены к группе слабоустойчивых с уровнем проросших семян в пределах 21,0-40,0 \%, среднеустойчивыми (41,0-60,0 \% проросших семян) были три сорта, устойчивыми $(61,0-80,0 \%)-12$ сортов, высокоустойчивыми $(81,0-100,0 \%)-17$ сортов. По урожайности согласно уровню превышения стандарта в пределах 53,0-117,0 \% выявлено семь сортов с урожайностью на уровне стандарта.

Выводы. По результатам трехлетних исследований 34 сортов сои отечественной селекции по уровню засухо- и холодоустойчивости соответственно доле проросших семян в условиях осмотика (засухоустойчивость) и холодного проращивания (холодостойкость) выделены сорта, соответствующих категории источников устойчивости к абиотическим факторам. Среди них 13 сортов с высокой холодоустойчивостью (75,9-99,3 \% проросших семян при пониженной положительной температуре $\left.+10,0^{\circ} \mathrm{C}\right)$ и 10 сортов со средней устойчивостью $(41,0-60,0 \%)$ к засухе.

Ключевые слова: сорт, соя, холодоустойчивость, засухоустойчивость, абиотический фактор, урожайность, адаптивность 
Kucherenko Ye.Yu., Petrenkova V.P.

Plant Production Institute named after V.Ya Yuriev of NAAS, Ukraine

The aim and tasks of the study. To evaluate drought- and cold-tolerance of modern soybean varieties bred at leading research institutions of Ukraine.

Material and methods. Laboratory (seed germinability in osmotic solution to determine drought tolerance and cold germination of seeds to determine cold tolerance). Field (yield capacity).

Results and discussion. Soybean varieties bred at the leading research institutions of the National Academy of Agrarian Sciences of Ukraine (13 varieties of the PPI nd. a. VYa Yuriev, 4 varieties of the NSC "Institute of Agriculture of NAAS", 4 varieties of the Plant Breeding and Genetics Institute - National Center of Seed and Cultivar Investigation, 4 varieties of the Institute of Oil Crops, 5 varieties of the Institute of Fodder and Agriculture of Podillia, and 4 varieties of Kirovohrad State Agricultural Experimental Station) were categorized into groups of drought- and cold-tolerance according to the results of laboratory analyses in 2015-2017. There was a slight difference in drought tolerance between varieties. Of the 34 test varieties, 2 varieties were classified as susceptible, as the percentage of seeds sprouted in osmotic solution did not exceed $20 \%$ related to the control. The slightly tolerant group consisted of 22 varieties, with the percentages of sprouted seeds of $21.0-40.0 \%$. The moderate tolerance was observed in 10 varieties (41.0-60.0\% of sprouted seeds related to the control). We detected no drought tolerant (61.0-80.0\% of sprouted seeds) or highly drought tolerant (81.0-100.0\%) soybean varieties. As to cold-tolerance groups, domestic soybean varieties were more variable judging by percentages of seeds sprouted at a low positive temperature $\left(+10.0^{\circ} \mathrm{C}\right)$. There were no susceptible varieties with the percentage of sprouted seeds of $0.0-20.0 \%$. Two varieties were slightly tolerant, with the percentages of sprouted seeds within $21.0-40.0 \% ; 3$ varieties were moderately tolerant (41.0-60.0\% of sprouted seeds); 12 varieties were tolerant $(61.0-80.0 \%)$; and 17 varieties were highly tolerant $(81.0-100.0 \%)$. Seven varieties had yields equal to or slightly higher than that of the standard variety (53.0-117.0\% related to the standard).

Conclusions. Based on the three-year study results, 34 soybean domestic varieties were evaluated for drought- and cold-tolerance in terms of percentages of seeds sprouted under osmotic pressure (drought-tolerance) or at the reduced temperature (cold-tolerance). We identified 13 varieties with high cold-tolerance $\left(75.9-99.3 \%\right.$ of seeds sprouted at $\left.+10.0^{\circ} \mathrm{C}\right)$ and 10 varieties with moderate drought-tolerance $(41.0-60.0 \%)$, which meet the requirements to sources of tolerance to abiotic factors.

Key words: soybean, varieties, cold-tolerance, drought-tolerance, abiotic factor, yield capacity, adaptability 